Citation: Uyar K. \& Somtaş Lekesizcan F. (2017), Markanın Benliği İfade Etmesi Ve Sosyal Görünürlüğünün Marka Aşk1 İle İlişkisi, BMIJ, (2017), 5(4): 154-171 doi: http://dx.doi.org/10.15295/bmij.v5i4.192

\title{
MARKANIN BENLİĞİ İFADE ETMESİ VE SOSYAL GÖRÜNÜRLÜĞÜNÜN MARKA AŞKI İLE ILIŞKKISI
}

\author{
Kumru UYAR ${ }^{1}$ \\ Feyza SOMTAŞ LEKESIZCAN ${ }^{2}$
}

\author{
Received Date (Başvuru Tarihi): 30/11/2017 \\ Accepted Date (Kabul Tarihi): 29/12/2017 \\ Published Date (Yayın Tarihi): 07/01/2018
}

öz

Bu çalışmanın konusuçok sınırlı sayıda çalışmada ele alınan marka aşkıdır. Tüketicinin işletme ile kurmuş olduğu duygusal bağın uzun dönemde sürdürülmesi marka aşkı kavramını günümüzde hem tüketiciler hem de üreticiler açısından oldukça önemli hale getirmektedir. Tüketiciler tarafindan sevilen bir marka rekabette çok büyük bir güç elde edebilmektedir. Çalışmanın temel amacı, marka aşkı ile markanın benliği ifade etmesi ve sosyal görünürlüğü arasındaki ilişkileri belirlemektir. Çalışmanın amaçları doğrultu sunda hazırlanan anket formu ile Kayseri il merkezinde yaşayan 459 tüketiciden toplanan veriler SPSS 22 paket programı ile analiz edilmiştir. Araştırmanın bulguları, markanın hem iç benliği hem de sosyal benliği ifade etmesi ile marka aşkı arasında iki boyut açısından da orta düzeyde ilişkiler olduğunu ortaya koymaktadır. Ayrıca marka aşkı ile markanın sosyal görünürlüğü arasında da orta düzeyde ilişki olduğu tespit edilmiştir. Markanın sosyal görünürlüğ̈̈, önceki literatürde ele alınmamıştır. Bu çalışmanın, marka aşkı literatüründe markanın sosyal görünürlüğünü ele alan ilk çalışma olarak konunun daha çok anlaşılmasına katkı sağlaması beklenmektedir.

Anahtar Kelimeler: Marka Aşkı, Benliği Iffade Eden Marka, Markanın Sosyal Görünürlüğü

JEL Kodlart: M10, M30, M31

\section{THE RELATIONSHIP BETWEEN SELF-EXPRESSION, SOCIAL VISIBILITY OF BRAND AND BRAND LOVE}

\begin{abstract}
The subject of this study is brand love, which is studied in a very limited number of studies. The long -term sustainability of the emotionalbond that the consumer has established with the business makes the concept ofbrand love very important for both consumers and manufacturers today. A brand loved by consumers can gain a great deal of strength in competition. The main goal of the study is to determine the relationship between brand love, selfexpression brand and social visibility ofbrand. In line with the aim, the study has been carried out through colleting primary data from the 459 consumers in Kayseri. The data were analyzed with the SPSS 22 package program. The findings of the research reveal that the brand love is related to as well as to the expression of inner selfand social self. It has also been found that there is a relationship between brand love and social visibility ofbrand. The social visibility ofbrand is not addressed in the previous literature. It is expected that this work will contribute to a better understanding of the issue as the first study to address the social visibility of the brand in the brand love literature.
\end{abstract}

Keywords: Brand Love, Self-Expression Brand, Social Visibility of Brand.

JEL Codes: M10, M30, M31

\footnotetext{
${ }^{1}$ Yrd. Doç. Dr. Nuh Naci Yazgan Üniversitesi kumruuyar@hotmail.com

${ }^{2}$ YLSÖğr., Nuh Naci Yazgan Üniversitesi, feyza_somtas@hotmail.com
}

http://orcid.org/0000-0002-2604-5317 http $/ /$ orcid.org/0000-0003-3955-8178 


\section{GİRis}

Günümüz artan rekabet koşullarında piyasaya sürülen yüzlerce marka arasından fark yaratıp tutunabilmek oldukça zorlaşmıştır. Marka sayısının her geçen gün artması marka kavramını önemsizleştirmiş ve bunun sonucu olarak da işletmeleri yeni arayışlar içerisine girmeye zorlamıştır. Markaların rekabette farklılaşabilmesinin tüketiciyle güçlü duygusal bağlar kurabilmesi ile mümkün olabileceği anlaşılmış ve firmalar faaliyetlerini bu yöne doğru çevirmeye başlamışlardır. Tüketiciyle kurulan güçlü bağ marka sadakati ile müşterilerin sürekliliğini sağlamaktadır (Whang, Allen, Sahoury \& Zhang, 2004). Shimp ve Madden (1988) tarafindan açıklandığından beri pazarlama literatüründe araştırmacılar marka aşkı kavramı üzerinde durmaktadırlar (Fournier, 1998; Whang, vd., 2004; Ahuvia, 2005; Ahuvia, Bagozzi \& Batra, 2007; Caroll \& Ahuvia, 2006; Bergkvist \& Bech-Larsen, 2010). Özellikle Carroll ve Ahuvia, (2006) ve Batra, Ahuvia ve Bagozzi, (2012) çalşsmalarıyla bu kavramın netleşmesine katkı sağlamışlardır. Bu çalışmada, tüm bu araştırmalardan farklı olarak markanın sosyal görünürlüğü ile marka aşkı arasında ilişki olup olmadığı da incelenerek konuya yeni bir boyut katılmaya çalşsılmıştır. Marka aşkı üzerine yapılan çalş̧ma bu kavramı çok daha iyi anlamamıza yardım edecektir. Marka aşkı kavramının önemini net olarak anlayabilmemiz için marka aşkının ilşskili olduğu kavramları da anlayabilmemiz gerekir. Çalışmada marka aşkı ile markanın benliği ifade etmesi ve sosyal görünürlüğü arasındaki ilişkileri tespit etmek amaçlanmaktadır.

$\mathrm{Bu}$ amaçla çalışmada ilk olarak kavramlarla ilgili hipotezlerin geliştirildiği kavramsal modele yer verilmektedir. Daha sonra çalışmanın metodolojisi yer almaktadır. Analiz ve bulgular tartışıldıktan sonra gelecekteki araştırmalar için önerilere ve çalşsmanın bazı sinırlılık larına değinilmektedir.

\section{KAVRAMSAL ÇERÇEVE}

\subsection{Marka Aşkı}

Tüketicilerde markaya yönelik duygular oluştuğunda markaya yönelmiş olan rasyonel düşüncelerin yerini duygusal anımsamalar ve çağrışımlar almaktadır. Bu duygusal olan anımsamalar genelde somut ögelerden ziyade soyut ögelerle ilişkilendirilmiştir (Pelsmacker \& Geuens, 1997). Markayla ilgili duygusal çağrışımlar tüketicilerin karar sürecini ve davranışlarını etkilemektedir (Belk, 1975; Chamberlain \& Broderick, 2007; Coricelli, Dolan \& Sirigu, 2007). Yapılan çalışmalar, duygular aracılı̆ıyla marka çağrışımı oluşturmanın satışları da olumlu etkilediğini ortaya koymaktadır (Pelsmacker \& Geuens, 1997). Tüketiciler binlerce 
markayı deneyimlemelerine rağmen bunlardan sadece birkaçına karşı güçlü duygular beslerler. Tüketicilerin ürüne yönelik ilgilenim düzeyleri marka sevgisini meydana getirmektedir. Fournier (1998) tüketicilerin markalarla güçlü ilişkiler geliştirebileceğini tespit etmiştir. Fournier, (1998)'e göre tüketici ve marka arasındaki güçlü ilişkinin temelinde sevgi ve tutku bulunmaktadır. Marka aşkı, konusundaki ilk açklamalar, kişiler arası sevgi ile tüketim nesneleri için sevgi arasındaki ilişkiyi savunan Shimp ve Madden (1988) tarafindan yapılmıştır. Carroll ve Ahuvia (2006) marka aşkını tüketicilerin bir markaya karşı duygusal ve tutkulu hisleri şeklinde tanımlamışlardır ve marka aşkının bir markayı beğenmekten çok daha yoğun bir duygusallık olduğunu belirtmişlerdir. Aynı şekilde Sarkar (2014)'te beğenmenin, marka için sıcak duygularla karakterize edilen bir başlangıç evresi olduğunu belirtmiştir. Kişi, olumlu olarak algilanan marka uyaranlarına maruz kaldıç̧a markayı sevmeye başlar. Bu sevgi tüketiciler markayı diğerlerinden çok daha çekici ve farkh buldukça yoğunlaşır ve tutkuya dönüşür. Aşk, sosyal aidiyet duygusu ile yakından alakalıdır ve markalar için tüketiciyle sosyal bağlam ve duygusal his gereklidir. Sarkar (2014)'ün çalışmasında görüştüğü tüketiciler, marka aşkı hakkındaki hislerini açıklarken, bağımlılık, takınt, delilik ve kendini kaybetme gibi kavramları kullanmışlardır. Marka sevgisi, uzun süren tüketici marka ilişkisinin bir sonucudur ve tatmin olmuş müşterilerden oluşmaktadır (Carrol \& Ahuvia, 2006; Keh, Pang \& Peng, 2007). Reklamlar ya da ağızdan ağza iletişim (WOM) gibi çeşitli marka uyarıcıları ile marka sevilme ye başlanır ve bu zamanla tutkuya dönüşerek uzun vadede bir beğenme ile marka aşkına dönüşmeye başlar. Pektaş, Erdem, Yıldız ve Karadeniz (2015)'in belirttiği gibi sosyal pazarlama uygulamaları da marka aşkının oluşmasında etkilidir. Marka aşkı; marka için tutku, ilişki, değer, pozitif duygusal bir cevap ve aşkın beyan edilmesini içermektedir (Carrol \& Ahuvia, 2006, s. 81). Tüketicilerin ürüne yönelik ilgilenim düzeyleri marka sevgisini meydana getirmektedir. Batra vd. (2012, s.5)'e göre marka aşkı, zihinsel bir prototip haline getirilmiş uzun dönemli birden fazla biliş, duygu ve davranış içerir. Rauschnabel, Ahuvia, Ivens \& Leischnig (2015) marka aşkına yol açan psikolojik faktörleri araştırdıkları çalışmalarında, dışa dönüklük ve nevrotikliğin marka aşkını arttırdığını tespit etmişlerdir. Yapılan çalışmalarla marka aşkının öncülleri ve sonuçları tespit edilmiştir (Bergkvist \& Bech-Larsen, 2010; Thomson, MacInnis \& Park, 2005; Robert, 2005; Patwardhan \& Balasubramanian, 2011; Fetscherin, 2014; Bıçakçığlu, İpek \& Bayraktaroğlu, 2016). Kang (2105) marka aşkının markaya yönelik tutum ve davranışları etkilediğini tespit etmiştir. Marka aşkının, Wom (Carroll \& Ahuvia, 2006; Wallace, Buil \& de Chernatony, 2014), marka bağllığı (Thomson vd., 2005; Carroll \& Ahuvia, 2006; Bergkvist \& Bech-Larsen, 2010; Wallace vd., 2014; Aydm, 2016; Aşkın \& İpek, 2016, Akın, 2017), tatmin (Thomson vd., 2005; Carroll \& Ahuvia, 2006; Özbek, 
Kutbay, \& Külahll, 2017), uzun süre kullanım (Thomson vd., 2005; Batra vd., 2012; Huber, Meyer, \& Schmid, 2015; Langner vd., 2016), tekrar satı alma niyeti (Aydın, 2016), fazla fiyat ödeme gönüllülüğü (Fournier 1998, Thomson vd., 2005; Carroll \& Ahuvia, 2006; Bayraktaroğlu \& Akyol, 2009; Heinrich, Albrecht \& Bauer, 2012, Albert, Merunka \& ValetteFlorence, 2013; Aydın, 2016), hedonik tüketim (Carroll \& Ahuvia, 2006), algilanan fonksiyonel kalite (Batra vd., 2012), tutumun gücü (Batra vd., 2012), markaya duyulan güven (Pawle \& Cooper, 2006; Turgut, 2014; Aydın, 2016; Özbek, Kutbay \& Külahll, 2017), markanın tüketiciyi ifade etmesi (Carroll \& Ahuvia, 2006; Wallace vd., 2014), marka kimliği (Bergkvist \& Bech-Larsen, 2010) negatif bilgiye direnç (Batra vd., 2012) ve markanın yaptığ1 hatalara karşı daha affedici olma (Bauer, Heinrich \& Albrecht, 2009) değişkenleri ile arasında ilişki olduğunu tespit edilmitir.

\subsection{Marka Aşkı Ve Benliği İfade Eden Markalar Arasındaki İlişki}

Benlik kişinin kendisini algılayış şeklidir (Odabaşı \& Barış, 2015, s.204). Benlik imajı, kişinin kendisine yönelik tutumları, duyguları ve algılarına ilişkin farkındalığıdır. Aynı zamanda benlik imajı, koruyucu olup insanı değerli kılar. İnsan davranışının temelindeki amaç benlik kavramını ya da benlik imajını korumak, arttırmak ve sürdürmektir (Markin, 1974'den aktaran Balikçığ lu \& Oflazoğlu, 2015, s. 24).

Keller (2008)'e göre, bir markanın en önemli özelliklerinden biri benliği ifade etme işlevidir. Tüketim artık sadece işlevsel değer demek değildir. Levy (1959), kişilerin ürünü satın alırken yalnızca işlevine değil taşıdı̆̆ anlama da baktıklarını ifade etmiştir. Bunu destekler şekilde tüketici davranışı literatüründe, tüketicilerin fonksiyonel değer ve sembolik anlamlar için ürünleri tükettikleri konusunda birçok kanıt vardır (Solomon, 1983; Sirgy \& Samli, 1985; Belk, 1988; Leigh \& Gabel, 1992; Kressmann, Sirgy, Herrmann, Huber \& Huber, 2006; Lee \& Hyman, 2008). Dolayısıyla markalar tüketicilerin kendi kişiliklerini oluşturmada ve tanımlamada kullandkları sembollerdir. Günümüz tüketicileri kendilerini tanımlamak ve kimliklerini toplum içinde ifade etmek için ürün ve markaları kendi amaçları için kullanırlar. İnsanlar tüketimleri ile kendi kimliklerini de inşa ederler (Rochberg \& Halton, 1984; Belk, 1988; Richins, 1994). Sahip olunan maddi varlk lar benliğin işaretleridir ve kişiliği oluşturmada ve benliği ifade etmede katkı sağlamaktadır (Belk, 1988; Ball \& Tasaki, 1992; Richins, 1994; Kleine, Kleine \& Allen, 1995; Fournier, 1998; Cătălin \& Andreea, 2014). Tüketiciler kendilerini tanımlamak için kimliklerini şekillendiren markalar kullanırlar (Malär, Krohmer, Hoyer \& Nyffenegger, 2011). Ayrıca, tüketiciler sosyal çevrelerindeki konumlarını belirlemelerine yardımc 
Ayvaz (2017)'ye göre reklamların ürün imajlarını yaratması ve bir yaşam tarzı sunması gibi bireyler de kendilerine satın almayı tercih ettikleri ürünlerle bir kimlik yaratıp aşı olunası metalara dönüştürmektedirler. Markalar benliğimizi ifade etmenin yanı sira sosyal ortamda diğer üyelerden farkhlaşma aracı olarak da hizmet eder. Tüketiciler, ürünleri ve markaları oluşturdukları imaja göre değerlendirirler. Tüketiciler sk s1k kendi benlik imajını geliştirebilecek ve sürdürebilecek ürünleri almayı tercih ederler (Levy,1959; Sirgy, 1986; Solomon \& Douglas, 1987). Kendi benlik imajına benzer bir markayı tercih etme eğilimi "İmaj Uyumu Hipotezi” olarak adlandırılmaktadır. Birçok çalışmada benlik imajı ile marka tercihi arasında pozitif yönlü bir ilişki olduğu tespit edilmiştir (Belk, Bahn \& Mayer, 1982; Onkvist \& Shaw, 1987; Hong \& Zinkhan, 1995; Graeff, 1997; Heath \& Scott,1998; Jamal \& Goode, 2001; King, 2002; Gross \& Brown, 2006; He \& Mukherjee, 2007). Carroll ve Ahuvia, (2006, s. 82) tüketiciyi ifade eden markayı, belirli markanın kişinin sosyal benliğini arttrrma ve/veya kişinin kendi özünü yansıtma derecesi ile ilgili tüketicilerin algları olarak tanımlamıştır. Bir markanın kişinin kendisini ifade etmesi derken sadece gerçek benliği değil aynı zamanda nasıl biri olarak görülmek istediği de önemlidir (Belch \& Landon, 1977). Carroll ve Ahuvia, (2006)'ya göre markanın benliği ifade etmesinde iç benlik ve sosyal benlik olmak üzere iki boyut vardır. Markalar bir yandan tüketicilerin kendi kişisel kimliğini yansıtan iç ya da gerçek benliklerini tanımlamalarına izin verir; öte yandan, kişinin kendisini toplumsal çevrede güçlendirmesi için bir araç olabilir. (Ahuvia, 2005; Carroll \& Ahuvia, 2006; Einwiller, Fedorikhin, Johnson \& Kamins 2006; Bergkvist \& Bech-Larsen, 2010; Wallace vd., 2014). Markanın benliği ifade etmesi, marka ile kişi arasındaki uyumla alakahdır (Vlachos, Theotokis, Pramatari \& Vrechopoulos, 2010) ve tatminle arasında güçlü bir ilişki vardır (He \& Mukherjee, 2007; Jamal \& Al-Marri, 2007). Araştırmacılar tüketiciyi yansıtan markaların marka aşkı üzerinde pozitif etkisi olduğunu tespit etmişlerdir (Carroll \& Ahuvia, 2006; Bergkvist \& Bech-Larsen, 2010; Hwang \& Kandampully, 2012; Batra vd., 2012; Loureiro, Ruediger \& Demetris, 2012; Albert vd., 2013; Wallace vd., 2014; Vernuccio, Pagani, Barbarossa \& Pastore, 2015; Huber vd., 2015). Bıçakçığlu vd. (2016) çahşmalarında marka aşkının öncülleri ve sonuçları arasındaki ilişkileri kavramsal model üzerinde bütünleşik bir biçimde sınamış ve bu model kapsamında benlik uyumunun marka aşkı üzerinde olumlu bir etkisi olduğunu tespit etmişlerdir. Literatürde böyle bir marka tanımlamanın önemi açıkça görülmektedir. Buna göre:

$\boldsymbol{H}_{1}$ : Markanın tüketicinin iç benliğini ifade etmesi ile marka aşkı arasında pozitifyönde bir ilişki vardır.

$\boldsymbol{H}_{2}$ : Markanın tüketicinin sosyal benliğini ifade etmesi ile marka aşkı arasında pozitifyönde bir ilişski vardır. 


\subsection{Marka Așkı Ve Markanın Sosyal Görünürlüğü Arasındaki ̇lişki}

Bearden ve Etzel (1982, s. 186)'ya göre tüketimlerinin başkaları tarafindan görülüp görülmemesine göre ürünler kamu ürünleri ve özel ürünler olarak iki gruba ayrllabilir. Kamu ürünü "başkalarının, sahip olunduğunun ve kullanıldığının farkında olduğu ürünlerdir" ve istedikleri takdirde, başkaları ürünün markasını kolaylıkla tanımlayabilir. $\mathrm{Bu}$ tanıma göre, kamusal ürün tüketimi özel ürünlerde olduğundan daha belirgin ve toplumsal açidan daha görünürdür. Kulviwat, Bruner ve Al-Shuridah (2009, s.707)'nin belirttikleri gibi, bazı ürünlerde o ürünün tüketildiğini aile üyeleri bile görmeyebilirken, kimi ürünlerde tüketim başkaları tarafindan rahatlkkla gözlemlenebilir. Araştırmacılar, bu kamusal / özel tüketim olgusunu çeşitli bağlamlarda araştırmışlardır (Raghunathan \& Corfman, 2006; Ratner \& Kahn, 2002; Sinha \& Mandel, 2008). İnsanlar, sosyal açıdan görünür ortamlarda diğerlerinden (ürün / marka seçimi açısmdan) daha fazla onaylama eğilimi gösterirler. Witt ve Bruce (1972) kamu ürünlerinde marka seçiminde, özel ürünlere göre daha büyük bir grup bağlllı̆̆1 tespit etmişlerdir. Aqueveque (2006) ürün görünür olduğunda, tüketicilerin genellikle gruba uyum sağlamaya çalşstılarını tespit etmiştir. Yüksek bir sosyal görünürlüğe sahip ürünlerin tüketimi, daha yüksek sosyal riskle bağlantılıdır (Solomon \& Douglas, 1987). Günümüzde tüketiciler kullandıkları marka ve markanın diğer tüketicileri ile arasında ilişkiler geliştirirler. Veloutsou ve Moutinho (2009) markanın sosyal görünürlüğünün marka ilişkilerinin oluşumunda etkisi olduğunu belirlemişlerdir. Graeff (1997) tüketimin sosyal görünürlük seviyesinin, tüketicilerin marka imajı ile davranışsal niyetleri arasındaki ilişkiyi etkilediğini tespit etmiştir. Literatürde tüketim faaliyetlerinin özel bir çevrede ya da tüketimin herkes tarafindan görülebileceği geniş bir kamusal alanda gerçekleşmesinin tüketim davranışlarını etkilediğiyle ilgili kantlar vardır (Bearden \& Etzel, 1982; Fisher \& Price, 1992; Kulviwat, Bruner \& Al-Shuridah, 2009). Markanı sosyal görünürlüğü markayla tüketicinin ilişkisini şekillendiren önemli bir faktördür. $\mathrm{Bu}$ sebeple çahı̧manın amaçlarından biri markanın görünürlüğünün marka aşkı ile ilişkisini tespit etmektir. Sosyal görünürlüğün yüksek olduğu durumlarda markaya yönelik duyguların daha yoğun yaşanacağı düşünülmektedir. Buna göre:

$\boldsymbol{H}_{3}$ : Markanın sosyal görünürlüğü ile marka aşkı arasında pozitifyönde bir ilişki vardır. 


\subsection{ARAŞTIRMANIN MODELI}

Araştırmanın modeli aşağıda Şekil 1'de görülmektedir.

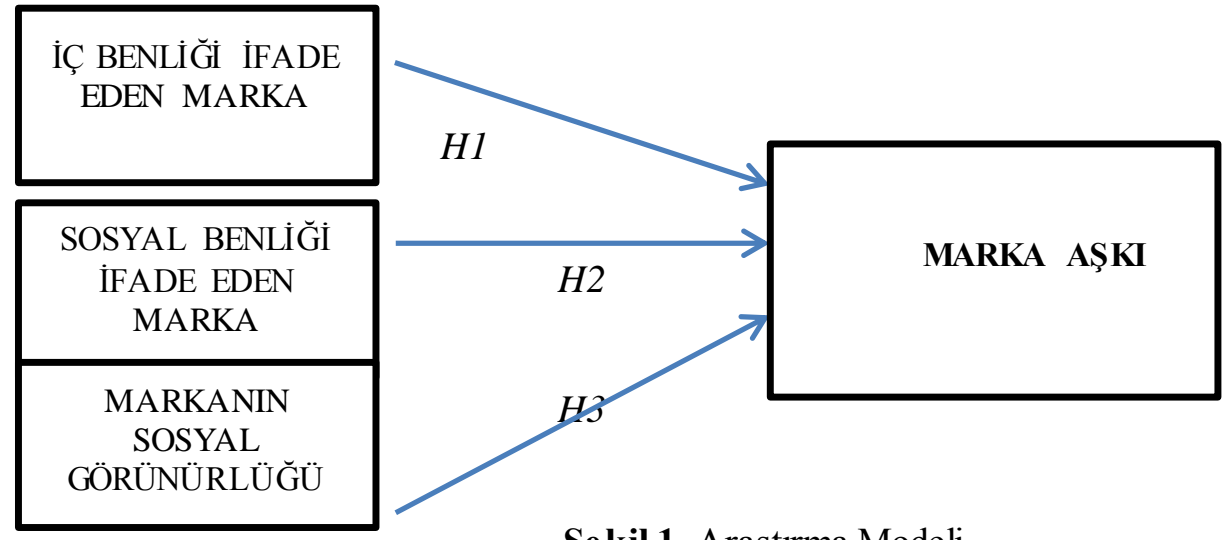

Şe kil 1. Araştırma Modeli

\section{YÖNTEM VE BULGULAR}

\section{1. Örneklem}

Marka aşkı ile markanın sosyal görünürlüğü ve markanın benliği ifade etmesi aralarındaki ilişkileri incelemek amaçlı oluşturulan bu çalş̧madaki örnek grubu, Kayseri ilinde yaşayan tüketicilerden seçilen 500 tüketiciden oluşmuştur. Analize uygun olmayan ve cevaplanmayan anketlerin 41 tanesinin elenerek çıarılması sonucu, analiz edilebilir anket sayıs1 (örnek büyüklüğü) 459'a inmiştir. Çalışmada tesadüfi olmayan örnekleme yöntemlerinden kolayda örnekleme yöntemi ile seçilen tüketicilerle yüz yüze anket yapılmıştır.

\subsection{Veri Toplama Aracı}

İlgi hipotezleri araştırmak için önerilen modeldeki tüm yapıları içeren araştırma aracı olarak tasarlanmış olan anket formu üç bölümden oluşmaktadır. Birinci bölümünde, katılımcılardan yoğun sevgi duydukları bir markayı belirtmeleri istenmiş ve böyle bir marka belirtilmediği durumda anket sonlandırılmıştır. İkinci bölümde, belirttikleri markayı düşünmelerini istemek suretiyle çalşmanın kavramsal modeline dahil edilen değişkenlere ait ölçek soruları katılımcılara yöneltilmiştir. Son bölümde ise demografik özellikleri tespit etmek amaçlanmıştır. Yaş ve gelir rasyo ölçme düzeyinde sorulmuştur.

Marka aşkı ile markanın benliği ifade etmesi ve sosyal görünürlüğü aralarındaki ilişkileri incelemek amaçh geliştirilen anket formu, literatürde uygulanmış, test edilmiş ve geçerliliği kanıtlanmış ölçekler incelenerek oluşturulmuştur. Bu ölçekler yabancı yazından elde edildiği için veri toplamaya başlamadan önce bir pilot çalışma yapılmış ve anket formu 
Kayseri'de kolayda örnekleme yolu ile seçilen 50 kişilik bir tüketici gurubu üzerinde uygulanarak muhtemel eksiklikler belirlenmeye çalşılmıştır. $\mathrm{Bu}$ pilot çalşsma srrasında tüketicilerin herhangi bir itirazları olmamış ve anlaşılmayan herhangi bir soruya rastlanmamıştır.

Anket formunda marka aşkını ölçen 13 ifade, markanın iç benliği ifade etmesini ölçen 5 ifade, markanın sosyal benliği ifade etmesini ölçen 3 ifade ve markanın sosyal görünürlüğünü ölçen 3 ifade yer almaktadır. Marka aşkını ölçen ifadeler Bagozzi, Batra \& Ahuvia (2016)'nın, markanın tüketicinin iç benliğini ve sosyal benliğini ifade etmesini ölçen ifadeler Carroll \& Ahuvia (2006)'nın ve markanın sosyal görünürlüğünü ölçen ifadeler Veloutsou ve Moutinho (2009)'nın çalşsmalarında kullanılan ölçeklerden uyarlanmıştır. Bu çalşsmada ölçeklerde 5'li likert tipi ölçek kullanılmıştır (1=Kesinlikle Katılmıyorum, 5=Kesinlikle Katılıyorum).

\subsection{Bulgular}

Veri analizinde SPSS 22 paket programı kullanılmıştır. Araştırmaya katılan 459 tüketicinin demografik özellikleri Tablo 1'de görülmektedir.

Araştırmaya katlanların \% 48,4'ünü kadınlar \% 51,6'sini ise erkekler oluşturmaktadır. Eğitim durumu açısından en yüksek dağlımın \% 52,3 ile üniversite mezunlarından oluştuğu görülmektedir. Medeni durum açısından bakıldığında araştırmaya katılanların büyük çoğunluğunu \%51,2 ile bekârlar oluşturmaktadır. Örnek grubun \%57'sini 17-28 yaşları arasındaki tüketiciler oluşturmaktadır. Araştırmaya katılanların büyük çoğunluğu \%36,5'lik bir oranla 3001-5000 TL gelir aralı̆̆ındadır. 
Tablo 1. Demografik Özellikler

\begin{tabular}{|c|c|c|c|}
\hline \multicolumn{2}{|c|}{ Demografik Özellikler } & $\mathrm{n}$ & $\%$ \\
\hline \multirow{3}{*}{ Cinsiyet } & Kadın & 222 & 48,4 \\
\hline & Erkek & 237 & 51,6 \\
\hline & Toplam & 459 & 100 \\
\hline \multirow{3}{*}{ Medeni Durum } & Evli & 224 & 48,8 \\
\hline & Bekâr & 235 & 51,2 \\
\hline & Toplam & 459 & 100 \\
\hline \multirow{5}{*}{ Yaş } & $17-28$ & 254 & 57 \\
\hline & $29-38$ & 112 & 25,1 \\
\hline & $39-48$ & 40 & 9 \\
\hline & 49 ve üstü & 40 & 9 \\
\hline & Toplam & 446 & 100 \\
\hline \multirow{5}{*}{ Eğitim Durumu } & İlköğretim & 19 & 4,1 \\
\hline & Lise ve Dengi & 133 & 29 \\
\hline & Üniversite & 240 & 52,3 \\
\hline & Y. Lis ans-Doktora & 67 & 14,6 \\
\hline & Toplam & 459 & 100 \\
\hline \multirow{6}{*}{ Gelir } & $1300-3000$ & 153 & 33,4 \\
\hline & $3001-5000$ & 167 & 36,5 \\
\hline & $5001-9000$ & 81 & 17,7 \\
\hline & $9001-15000$ & 47 & 10,3 \\
\hline & 15000 ve üstü & 10 & 2,2 \\
\hline & Toplam & 458 & 100 \\
\hline
\end{tabular}

Ölçeklerin güvenilirliği, Cronbach’s alpha katsayısı kullanılarak test edilmiştir. İç tutarlılığı ölçmede en yaygın kullanılan ölçek Cronbach alpha olarak da bilinen alfa katsayısıdır (Altunışık, Coşkun, Bayraktaroğlu \& Ylddrım, 2007, s. 115). Aşağıda yer alan tablo 2'de güvenilirlik sonuçları yer almaktadır.

Tablo 2. Ölçeklerin Güvenilirlikleri

\begin{tabular}{|c|c|}
\hline ÖLÇEKLER & CRONBACH'S ALPHA \\
\hline Marka Aşkı & 0,889 \\
\hline Tüketiciyi İfade Eden Marka (İç Benlilik) & 0,940 \\
\hline Tüketiciyi İfade Eden Marka (Sosyal Benlilik) & 0,879 \\
\hline Markanı̈n Sosyal Görünürlüğü & 0,783 \\
\hline
\end{tabular}

Cronbach's alpha değerinin 0.70 ve üstü olduğu durumlarda ölçeğin güvenilir olduğu ifade edilmektedir (Durmuş, Çinko \& Yurtkoru, 2011, s. 89). Kullanılan ölçeklerin cronbach's alpha değerleri 0,783-0,940 arasında olduğu için ölçekler güvenilirdir. 
Tüketicilerin marka aşkı ölçeğinde yer alan ifadelere katılım düzeylerinin ortalama ve standart sapmaları Tablo 3'de verilmektedir.

Tablo 3. Marka Aşkı İfadelerinin Ortalama ve Standart Sapma Değerleri

\begin{tabular}{|c|c|c|c|}
\hline Marka Aş kı & $\mathbf{n}$ & Ortalama & $\begin{array}{c}\text { Standart } \\
\text { Sapma }\end{array}$ \\
\hline $\begin{array}{c}\text { X Markasını kullanmamın kim olduğum hakkında doğru ve derin bir } \\
\text { șeyler söylediğini his sediyorum }\end{array}$ & 459 & 3,207 & 1,296 \\
\hline X Markası olmak istediğim kişi olmamı sağlıyor. & 459 & 3,169 & 1,263 \\
\hline X Markası yaşamımı daha anlamlı kılar & 459 & 3,220 & 1,247 \\
\hline Kendimi sıklıkla X markasını düşünürken buluyorum & 459 & 2,732 & 1,225 \\
\hline $\begin{array}{l}\text { X Markasından bir ürün satın aldıktan sonra iyileştirmek ve daha } \\
\text { uygun hale getirmek için çok fazla para harcamaya gönüllüyüm. }\end{array}$ & 459 & 2,899 & 1,258 \\
\hline S1klıkla X markasını kullanmayı arzu ediyorum & 459 & 3,631 & 1,151 \\
\hline Geçmişte X markas1 ile etkileşimim oldu & 459 & 3,485 & 1,224 \\
\hline $\mathrm{X}$ markası ile aramızda doğal bir uyum olduğunu hiss ediyorum & 459 & 3,455 & 1,163 \\
\hline X markasına duygusalaçıdan bağlı olduğumu hissediyorum & 459 & 3,156 & 1,240 \\
\hline X markasın1 eğlenceli buluyorum & 459 & 3,573 & 1,213 \\
\hline $\mathrm{X}$ markasını uzun süre daha tercih edeceğimi düşünüyorum & 459 & 4,039 & 1,124 \\
\hline X markasının olmadığını düşündügüümde kaygılanırım & 459 & 3,287 & 1,283 \\
\hline $\mathrm{X}$ markasına karşı his lerim olumludur & 459 & 4,058 & 1,002 \\
\hline
\end{tabular}

Cevaplayıcıların en çok katıldık ları ifade 4,058 ortalama ile 'X markasına karşı hislerim olumludur" ifadesid ir.

Tüketicilerin benliği ifade eden marka ölçeğinde yer alan ifadelere katılım düzeylerinin ortalama ve standart sapmaları Tablo 4'te verilmektedir.

Tablo 4. Benliği İfade Eden Marka İfadelerinin Ortalama ve Standart Sapma Değerleri

\begin{tabular}{|c|c|c|c|}
\hline Benliği İfade Eden Marka & $\mathbf{n}$ & Ortalama & $\begin{array}{c}\text { Standart } \\
\text { Sapma }\end{array}$ \\
\hline \multicolumn{4}{|l|}{ İç Benlik } \\
\hline X Markası gerçekte içimdeki kişiyi sembolize eder & 459 & 3,200 & 1,221 \\
\hline X Markası kişiliğimi yansıtır & 459 & 3,187 & 1,236 \\
\hline X Markası içimdeki benin bir uzantısıdır & 459 & 3,076 & 1,231 \\
\hline X Markası gerçek beni yansıtır & 459 & 3,141 & 1,244 \\
\hline X Markası benlik imajıma katkıda bulunur & 459 & 3,281 & 1,252 \\
\hline \multicolumn{4}{|l|}{ Sosyal Benlik } \\
\hline X Markası sosyal rolüme katkı sağlar & 459 & 3,291 & 1,280 \\
\hline $\begin{array}{c}\text { X Markası diğerlerinin benimle ilgili düşünceleri üzerinde olumlu } \\
\text { etki sağlıyor }\end{array}$ & 459 & 3,239 & 1,223 \\
\hline X Markası toplumun bana dair görüşünü olumlu hale getiriyor & 459 & 3,141 & 1,244 \\
\hline
\end{tabular}

Cevaplayıcıların en çok katıldıkları ifade 3,291ortalama ile "X Markası sosyal rolüme katk1 sağlar” ifadesidir.

Tüketicilerin markanın sosyal görünürlüğü ölçeğinde yer alan ifadelere katılım düzeylerinin ortalama ve standart sapmaları tablo 5 'te verilmektedir. 
Tablo 5. Markanın Sosyal Görünürlüğü İfadelerinin Ortalama ve Standart Sapma Değerleri

\begin{tabular}{|c|c|c|c|}
\hline Markanın Sosyal Görünürlüğü & n & Ortalama & $\begin{array}{c}\text { Standart } \\
\text { Sapma }\end{array}$ \\
\hline Nereye gidersem gideyim X markası var & 459 & 3,383 & 1,264 \\
\hline Ben X markasına sahip olan birçok insan tanıorum & 459 & 3,803 & 1,102 \\
\hline İnsanların X markası hakkında iyi hissettiklerini biliyorum & 459 & 3,745 & 1,173 \\
\hline
\end{tabular}

Cevaplayıcıların en çok katıldıkları ifade 3,803 ortalama ile "Ben X markasına sahip olan birçok insan tanıyorum" ifadesidir.

Marka aşkı ile benliği ifade eden marka (iç ve sosyal benlik) ve markanın sosyal görünürlüğünden oluşan bağımsız değişkenler arasında ilişki olup olmadığı korelasyon analizi ile araştırılmıştır. $\mathrm{Bu}$ analiz sonucu elde edilen veriler aşağıda Tablo 6'da görülmektedir. Korelasyon analizinin sonucuna göre marka aşkı ile tüm bağımsız değişkenler arasında $(0,01$ anlamlılık düzeyinde) istatistiksel olarak anlamlı pozitif yönde ilişkiler vardır.

Tablo 6. Marka Aşkı ve Bağımsız Değişkenler Arasındaki İlişkiler

\begin{tabular}{|c|c|c|c|}
\hline Marka Aşkı & $\begin{array}{c}\text { İç Benliği İfade Eden } \\
\text { Marka }\end{array}$ & $\begin{array}{c}\text { Sosyal Benliği İfade } \\
\text { Eden Marka }\end{array}$ & Sosyal Görünürlük \\
\hline $\mathbf{r}$ &, $637^{* *}$ &, $620^{* *}$ &, $403^{* *}$ \\
\hline $\mathbf{p}$ &, 000 &, 000 &, 000 \\
\hline $\mathbf{n}$ & 459 & 459 & 459 \\
\hline
\end{tabular}

** Korelasyon 0,01 düzeyinde anlamlı (tek uçlu test)

Marka aşkı ile markanın tüketicinin iç benliğini ifade etmesi arasında orta düzeyde bir ilişki vardır $(r=0,637)$. Bu sonuca göre markanın iç benliği ifade etme gücü arttıç̧a marka aşkının da artacağı söylenebilir. Marka aşkı ile markanın sosyal benliği ifade etmesi arasında orta düzeyde bir ilişki vardır $(\mathrm{r}=0,620)$. Bu sonuca göre markanın sosyal benliğini ifade etme gücü arttıça marka aşkının da artacağı söylenebilir. Marka aşkı ile markanın sosyal görünürlüğg̈ arasmda orta düzeyde bir ilişki vardır $(r=0,403)$. Bu sonuca göre markanı sosyal görünürlüğü arttıç̧a marka aşkının da artacağı söylenebilir.

Marka aşkında meydana gelen değişimlerin ne kadarının bağımsız değişkenlerle açıklandığını belirlemek amacıyla ise regresyon analizi yapılmıştır. Bağımsız değişkenler; iç ve sosyal benliği ifade eden marka ve markanın sosyal görünürlüğü olarak belirlenmiştir. $\mathrm{Bu}$ amaçla yapılan regresyon analizinin sonucu Tablo 7'de yer almaktadır. 
Tablo 7. Marka Aşkı Üzerinde Bağımsız Değişkenlerin Etkisi

\begin{tabular}{|c|c|c|c|}
\hline Marka Aşkı & Beta Katsayıları & t Değeri & Anlamlılık Düzeyi \\
\hline $\begin{array}{c}\text { İç Benliği İfade Eden } \\
\text { Marka }\end{array}$ &, 342 & 6,422 &, 000 \\
\hline $\begin{array}{c}\text { Sosyal Benliği İfade } \\
\text { Eden Marka }\end{array}$ &, 298 & 5,646 &, 000 \\
\hline Sosyal Görünürlük &, 180 & 4,922 &, 000 \\
\hline $\mathrm{R}=, 689 \quad \mathrm{R}^{2}=, 475$ & Ayarlanmıs $\mathrm{R}^{2}=, 471$ & $\mathrm{~F}=137,054 \quad$ Anlamlılık Düzeyi=,000 \\
\hline
\end{tabular}

$\mathrm{Y}=\mathrm{a}+\mathrm{b} 1 \mathrm{x} 1+\mathrm{b} 2 \times 2+\mathrm{b} 3 \times 3$

$\mathrm{Y}=1,398+0,342 * \mathrm{x} 1+0,298 * \mathrm{x} 2+0,180 * \mathrm{x} 3$

Analiz sonucuna göre marka aşkı ile değişkenler arasındaki ilişki istatistiksel olarak anlamlı bulunmuştur $(\mathrm{p}<0,05)$. Değişkenler arasında pozitif yönlü nispeten yüksek düzeyde bir ilişki vardır $(\mathrm{r}=0,689)$. Modelin açıklayıcılık düzeyi bakıldığında (Ayarlanmış $\left.\mathrm{R}^{2}=0,471\right)$ marka aşkındaki değişimlerin \% 47'sinin değişkenlere bağh olduğu söylenebilir. Tablo 7'de modelde yer alan her değişkenin standart beta katsaylları, $\mathrm{t}$ değerleri ve önem düzeyleri verilmiştir. Tablodan görüleceği gibi analize dahil edilen değişkenlerin iki tanesinin bağımlı değişken üzerindeki nispi etkisi istatistiksel olarak anlamlıdır. Bağımlı değişkendeki değişmeyi açıklayan en önemli faktör markanın iç benliği ifade etmesidir. Tüketicinin iç benliğini ifade eden marka ile marka aşkı arasındaki ilişki pozitif yönlüdür $(0,324)$. Yani, markanın iç benliği ifade etme gücü arttıça marka aşkının da artacağı söylenebilir. Sosyal benliği ifade eden marka ile marka aşk1 arasındaki ilişki pozitif yönlüdür $(0,298)$. Yani, markanın sosyal benliği ifade etme gücü arttıkça marka aşkının da artacağı söylenebilir. Markanın sosyal görünürlüğü ile marka aşk1 arasmdaki ilişki pozitif yönlüdür $(0,180)$. Markanın sosyal görünürlüğü arttıç̧a marka aşkının da artacağı söylenebilir.

Aşağıdaki tablo 8'de çalısmanın hipotezleri ve bu hipotezlerin karar durumları gösterilmiştir.

Tablo 8. Analiz Sonucuna Göre Hipotezlerin Kabul/Ret Durumu

\begin{tabular}{|c|c|}
\hline HiPOTEZ & Karar \\
\hline $\begin{array}{c}\text { Markanın tüketicinin iç benliğini ifade etmesi ile marka aşkı arasında pozitif yönde bir ilişki } \\
\text { vardır. }\end{array}$ & KABUL \\
\hline $\begin{array}{c}\text { Markanın tüketicinin sosyalbenliğini ifade etmesi ile marka aşkı aras ında pozitif yönde bir } \\
\text { ilişki vardır. }\end{array}$ & KABUL \\
\hline Markanın sosyalgörünürlüğü ile marka arasında pozitif yönde bir ilişki vardır. & KABUL \\
\hline
\end{tabular}

\section{SONUÇ VE TARTIŞMA}

Aşsk gibi duygusal yapılar, güçlü tüketici marka ilişkileri içinde önemli bir rol oynadığı için, bu çahş̧mada marka aşkının altında yatan unsurlara odaklanılmıştır. Çalışma tüketici marka ilişkilerinin daha iyi anlanmasına yardımcı olmak için katkılar sağlamaktadır. 
Özellikle tüketicinin yoğun duygular beslediği markalar için aşkın oluşması hakkında bilgiler verilmektedir. $\mathrm{Bu}$ bilgiler, heyecanlı ve tutkulu bir marka yaratarak potansiyel ve mevcut müşterileri ile ilişkilerini uzun vadeli olarak iyileştirmeyi amaçlayan pazarlamacılar için son derece önemlidir. Carroll ve Ahuvia (2006) tarafindan önerilen modelin ardından bu araştırma, marka aşkının öncüsü olarak markanın benliği ifade etmesi (iç-sosyal benlik) ve sosyal görünürlüğünü incelemektedir. Çalışmanın temel amacı, tüketicilerin kullandıkları bir marka ile ilgili geliştirdikleri marka aşkı ile markanın benliği ifade etmesi ve sosyal görünürlüğü arasındaki ilişkilerin araştırılmasıdır. Marka aşkı kavrami; yerli literatürde az sayıda çalışmada ele alınmıştır. Bu sebeple bu çalışma ile literatüre katkı sağlamak hedeflenmektedir.

Literatürdeki çalş̧malar benliği ifade eden markaların marka aşkı üzerinde pozitif etkisi olduğunu tespit etmişlerdir (Carroll \& Ahuvia, 2006; Bergkvist \& Bech-Larsen, 2010; Hwang \& Kandampully, 2012; Batra vd., 2012; Loureiro vd., 2012; Albert vd., 2013; Wallace vd., 2014; Vernuccio vd., 2015; Huber vd., 2015; Bıçakçığlu vd., 2016). Bu sonuçlarla uyumlu olarak çalışmada da marka aşkı ile markanın benliği ifade etmesi arasında iki boyut açısından da orta düzeyde ilişki tespit edilmiştir. Bu sonuçlara göre marka tüketicinin iç ve sosyal benliğini yansitıyorsa, marka aşkının da artacağı söylenebilir. Bu çalşsma tüketicile rin markalar yoluyla iç benlik ve sosyal benliklerini tanımlayarak kimliklerini ortaya koyabildiklerini algıladıkları markalara karşı daha fazla marka aşkı oluşturduklarını göstermektedir. Markanın benliği ifade etmesi marka aşkı için önemli bir öncüldür. Elde edilen sonuçlara göre markanın iç benliği ifade etmesi marka aşk1 üzerinde sosyal benliği ifade etmesine göre daha etkili bulunmuştur. Tüketicilerin sosyal benlikten çok iç benliğe odaklandık ları söylenebilir.

Çalışmada marka aşkı ile ilişkisi açısından ele alınan markanın sosyal görünürlügü daha önce literatürde hiç bir çalışmada bu kapsamda incelenmemiştir. Bu yönüyle de çalışma literatüre katkı sağlamaktadır. Bireylerin en temel ihtiyaçları arasında bir topluluğa ait olma, sevilme, saygı görme gibi ihtiyaçlarda vardır. Bireyler bu ihtiyaçlarını karşıladıç̧a mutluluk ları artacaktır. Günümüzde ürünler bireylerin bu ihtiyaçlarına ulaşmalarında önemli bir araç olmaktadır. Artık ürünlerin değişim değerlerinden çok gösterim değeri ön plandadır. Tüketiciler kullandkkları ürünlerden bu yönde bir sosyal fayda sağlıyorsa ürünün tüketici için değeri daha çok artmaktadır. Böylece tüketicilerin bu tarz bir tüketimden elde ettikleri haz daha fazla artmaktadır. Özellikle bu sosyal etki görünür markalarda daha önemli olmaktadır. Çalışmada marka aşkı ile markanın sosyal görünürlüğü arasında orta düzeyde bir ilişki tespit edilmiştir. $\mathrm{Bu}$ sonuca göre markanı sosyal boyutu arttıkça marka aşkının da artacağı söylenebilir. 
Pazarlama yöneticileri markalarının sosyal görünürlüğünü arttıracak stratejiler geliştirmelidirler. Sosyal görünürlügü yüksek olan ürünlerde, sosyal etki faktörü tutundurma kararlarında dikkate alınmalıdır. Referans grupları aracilğıyla ağızdan ağıza pazarlamaya yönelerek marka aşkı oluşturmaya çalışılmalıdır. Tüketimin sosyal görünürlüğü seviyesi, tüketicilerin marka imajı ve davranışsal niyeti arasındaki ilişkiyi etkiler (Graeff, 1997). Bu nedenle, etkili bir marka imajı geliştirilebilmesi için pazarlama yöneticileri ürünün tüketildiği şartları ve potansiyel durumları göz önünde bulundurmalıdır.

Marka aşkının işletmelerin pazarlama hedefleri üzerindeki etkisi göz ardı edilemez. Pazarlama yöneticileri için marka aşkı, tüketicilerle kalıı bir duygusal ilişki kurabilmeleri için son derece önemlidir. Günümüzde çok az sayıda marka müşterileri ile aşk gibi duygusal bir bağ oluşturabilmiştir. Marka aşkı oluşması sürecini daha iyi anlayabilen firmalar daha güçlü ve başarılı stratejiler geliştirebileceklerdir. Bunu başaran markalar bu bağllı̆̆ın kendilerine sağladığı sınırsız faydaların açtığı yolda sorunsuzca ilerlemektedirler. Bu tür bir duygusal bağ markaya duyulan güven ve bağlılık üzerinde olumlu etkide bulunmaktadır. Bu sebeple firmalar için marka aşkı yaratmak son derece önemlidir. Bu çahşma ile marka aşkının oluşmasında etkili olan benliği ifade eden marka (iç-sosyal benlik) ve markanın sosyal görünürlüğünden oluşan değişkenler incelenmiştir. Marka aşkındaki değişimlerin \% 47'sinin bu değişkenlerle açıklanabileceği tespit edilmiştir. Bu sonuca göre marka aşkı oluşturmak isteyen firmalar strateji geliştirirken bu değişkenlere dikkat etmelidir. Firmalar tekliflerinin bu yönlerini güçlend irmenin, tüketicilerdeki bu yoğun duygusal tepkiyi arttırdığını görebilirler. Firmaların, tüketicilerin benliklerine uygun mal ve hizmetler ortaya koyabilmeleri için öncelikle hedef pazarlarındaki tüketicileri çok iyi tanımaları gereklidir. Buna göre, marka yöneticileri hedef tüketicilerin benlik özelliklerini tespit etmeli ve bu yönde bir marka imajı geliştirilmelidir. Bunun sonucunda marka aşkı oluşturabilirler.

Her araştırmada olduğu gibi bu araştırmada da bir takım sınırlılıklar bulunmaktadır. Araştırmanın en önemli smırlılığı seçilen örnek kütle ve araştırmanın kapsamılyla ilgilidir. Zaman ve maliyet kıstlarından dolayı araştırma kapsamı sadece bir ilden tüketicilerin seçilmesiyle sınırlandırılmış ve araştırma sadece Kayseri ilinde gerçekleştirilmiştir. İkinci kısıt, olasıllk örneklemesinin yapılmamış olmasıdır. $\mathrm{Bu}$ nedenle de, bulgularla ilgili genellemeler yapılırken olasılık dışı örneklemenin kullanılmış olması gerçeği göz önüne alınmalıdır. Üçüncü kısıt ise bu araştırmada markalar ve sektörler arasındaki farklılkların dikkate alınmamasıdır. 
Bundan sonra yapılacak olan çahşmalarda marka aşkımı etkileyen daha fazla değişken araştırmaya dahil edilebilir. Gelecek çalışmalarda farklı sektörler ve markalar açısından inceleme yapılabilir. Ayrıca çalısmayı farklı kültürlerde uygulayarak, bulgular literatüre katkıda bulunacak şekilde farklı kültürler arasında karşışştırılabilir. 


\section{KAYNAKÇA}

Akın, M. (2017). "The effects of young consumers' love for smart mobile phone brands on brand loyalty", International review of management and business research, 6(1), 362-370.

Albert, N., Merunka, D. \& Valette-Florence, P. (2013). “Brand passion: antecedents and consequences”, Journal of Business Research, 66 (7), 904-909.

Altunışık, R., Coşkun, R., Bayraktaroğlu, S., \& Yıldırım, E. (2007). Sosyal bilimlerde araştırma yöntemleri. Sakarya Yayınc1lı, Sakarya.

Aşkın, N., \& İpek, I. (2016). "Marka aşkının marka deneyimi ile marka sadakati arasındaki ilişkiye aracılık etkisi”, Ege akademik bakış, 16(1), 79-94.

Aydın, H. (2016). "Marka aşkının değerlendirilmesi: Beyaz eşya kullanıcıları üzerine bir araştırma”. Tüketici ve Tüketim Araştırmaları Dergisi, 8 (2) 125-149.

Ayvaz, S. (2017). “Aşkın tüketim kültürü üzerinden yeniden anlamlandırılması: markafoni örneği”. Ankara üniversitesi İLEF dergisi, 4(1), 149-170.

Ball, A. D. \& Tasaki, L. H. (1992). "The role and measurement of attachment in consumer behavior", Journal of consumer psychology, 1(2), 155-172.

Batra, R., Ahuvia, A. \& Bagozzi, R. P. (2012). "Brand love”, Journal of marketing, 76(2), 1-16.

Bauer, H., Heinrich, D. \& Albrecht, C. M. (2009). "All you need is love: Assessing consumers' brand love", In Proceedings of the American Marketing Association summer educators conference , 252-53, Chicago: American Marketing Association.

Balıkçığlu, B., \& Oflazoğlu, S. (2015). "Marka Evangelizmi, Benlik-Marka Imaji Uyumu ve Marka Sadakati Iliskisi Üzerine Ampirik Bir Arastirma”. Tüketici ve Tüketim Araştırmaları Dergisi, 7(2), 19-45.

Bearden, W. O. \& Etzel, M. J. (1982). "Reference group influence on product and brand purchase decisions", Journal of consumer research, 9(2), 183-194.

Belch, G. E. \& Landon Jr, E. L. (1977). “Discriminant validity of a product-anchored self-concept measure”, Journal of Marketing Research, 14 (May), 252-256.

Belk, R. W. (1975). "Situational variables and consumer behavior”, Journal of Consumer research, 2(3), 157-164.

Belk, R. W. (1988). “Possessions and the Extended Self,” Journal of Consumer Research, 15(2), 139-68.

Belk, R. W., Bahn, K. D. \& Mayer, R. N. (1982). “Developmental recognition of consumption symbolism”. Journal of consumer research, $9(1), 4-17$.

Bergkvist, L. \& Bech-Larsen, T. (2010). "Two studies of consequences and actionable antecedents of brand love”, Journal of brand management, 17(7), 504-518.

Bıçakcıŏlu, N., İpek, İ., \& Bayraktaroğlu, G. (2016). Antecedents and outcomes of brand love: the mediating role of brand loyalty. Journal of Marketing Communications, 1-15.

Carroll, B. A. \& Ahuvia, A. C. (2006). "Some antecedents and outcomes of brand love", Marketing letters, 17(2), 79-89.

Cătălin, M. C., \& Andreea, P. (2014)."Brands as a mean of consumer self-expression and desired personal lifestyle". Procedia-Social and Behavioral Sciences, 109, 103-107.

Chamberlain, L. \& Broderick, A. J. (2007). "The application of physiological observation methods to emotion research". Qualitative Market Research: An International Journal, 10(2), 199-216.

Coricelli, G., Dolan, R. J. \& Sirigu, A. (2007). "Brain, emotion and decision making: the paradigmatic example of regret", Trends in cognitive sciences, 11(6), 258-265. 
Durmuş, B., Çinko, M. \& Yurtkoru, S. (2011). Sosyal bilimlerde SPSS’le veri analizi, 4. Baskı, Beta Yayıncılık, İstanbul.

Einwiller, S.A., Fedorikhin, A., Johnson, A.R. \& Kamins, M.A. (2006). "Enough is enough! When identification no longer prevents negative corporate as sociations", Journal of the Academy of Marketing Science, 34 (2), 185 194.

Fetscherin, M. (2014). "What type of relationship do we have with loved brands?”, Journal of Consumer Marketing, $31(6 / 7), 430-440$.

Fournier, S. (1998). "Consumers and their brands: Developing relationship theory in consumer research", Journal of consumer research, 24(4), 343-373.

Graeff, T. R. (1997). “Consumption situations and the effects of brand image on consumers' brand evaluat ions", Psychology ve Marketing, 14(1), 49-70.

Gross, M. J. \& Brown, G. (2006). "Tourism experiences in a lifestyle destination setting: The roles of involvement and place attachment", Journal of business research, 59(6), 696-700.

He, H. \& Mukherjee, A. (2007). "I am, ergo I shop: does store image congruity explain shopping behaviour of Chinese consumers?", Journal of Marketing Management, 23(5-6), 443-460.

Heinrich, D., Albrecht, C. M. \& Bauer, H. H. (2012). Love actually? Measuring and exploring consumers'brand love. Consumer-Brand Relationships-Theory and Practice. London: Routledge, 137-150.

Huber, F., Meyer, F. \& Schmid, D. A. (2015). "Brand love in progress -the interdependence of brand love antecedents in consideration of relationship duration". Journal of Product \& Brand Management, 24(6), 567-579.

Hwang, J. Y. \& Kandampully, J. (2012). “The Role of Self-Construal and Emotionsin Younger Consumers' Commitment to Luxury Brands". The Research Journal of the Costume Culture, 20(4), 604-615.

Ismail, R. A. \& Spinelli, G. (2012). "Effects of brand love, personality and image on word of mouth: The case of fashion brands among young consumers". Journal of Fashion Marketing and Management: An International Journal, 16(4), 386-398.

Jamal, A. \& Goode, M. M. (2001), “Consumers and brands: a study of the impact of self-image congruence on brand preference and satisfaction", Marketing Intelligence ve Planning, 19(7), 482-492.

Jamal, A. \& Al-Marri, M. (2007). "Exploring the effect of self-image congruence and brand preference on satisfaction: the role of expertise", Journal of Marketing Management, 23(7-8), 613-629.

Kang, A. (2015). "Brand Love-Moving Beyond Loyalty An Empirical Investigation of Perceived Brand Love of Indian Consumer". Arab Economic and Business Journal, 10(2), 90-101.

Keh, H. T., Pang, J. \& Peng, S. (2007). “Understanding and measuring brand love”, In Society for Consumer Psychology Conference Proceedings, 84-88.

Keller K.L. (2008) Strategic brand management - Building, measuring and managing brand equity, upper saddle river, NJ: Prentice Hall.

Kleine, S. S., Kleine, R. E. \& Allen, C. T. (1995). "How is a possession "me" or "not me"? Characterizing types and an antecedent of material possession attachment", Journal of consumer research, 22(3), 327-343.

Kressmann, F., Sirgy, M. J., Herrmann, A., Huber, F., Huber, S. \& Lee, D. J. (2006), "Direct and indirect effects of self-image congruence on brand loyalty”, Journal of Business Research, 59(9), 955-964.

Kulviwat, S., Bruner, G. C. \& Al-Shuridah, O. (2009). "The role of social influence on adoption of high tech innovations: The moderating effect of public/private consumption". Journal of Business Research, 62(7), 706-712.

Lee, D. \& Hyman, M. R. (2008). "Hedonic/functional congruity between stores and private label brands", Journal of Marketing Theory and Practice, 16(3), 219-232. 
Leigh, J. H. \& Gabel, T. G. (1992). "Symbolic interactionism: its effects on consumer behaviour and implications for marketing strategy", Journal of Services Marketing, 6(3), 5-16.

Loureiro, S. M. C., Ruediger, K. H., \& Demetris, V. (2012). "Brand emotional connection and loyalty". Journal of Brand Management, 20(1), 13-27.

Malär, L., Krohmer, H., Hoyer, W. D. \& Nyffenegger, B. (2011). "Emotional brand attachment and brand personality: The relative importance of the actual and the ideal self'. Journal of Marketing, 75(4), 35-52.

Odabaşı, Y., \& Barış, G. (2015). Tüketici davranışı. MediaCat Akademi.

Özbek, V., A. Yıldırım., O. Doğan, A. Külahlı, (2017). “Antecedents ofbrand love: a research on bank customers”, Press Academia Procedia (PAP), 3, 609-619.

Patwardhan, H., \& Balasubramanian, S. K. (2011). Brand romance: a complementary approach to explain emotional attachment toward brands. Journal of Product \& Brand Management, 20(4), 297-308.

Pektaş G. E., Erdem O., Yıldız E., \& Karadeniz M. “SosyalPazarlama Uygulamalarının Marka Aşkı Aracılı̆̆ı Rolü ile Tüketici Satın Alma Davranışına Etkisi: Deterjan Pazarı Üzerinde Bir Araştırma”, 20. Ulusal Pazarlama Kongresi, 10-13 Haziran 2015, 717-720, Eskişehir.

Rauschnabel, P., Ahuvia, A., Ivens, B. \& Leischnig, A. (2015). The personality of brand lovers. In Consumer Brand Relationships (pp. 108-122). Palgrave Macmillan UK.

Richins, M. L. (1994), "Valuing Things: The Public and Private Meanings of Possessions", Journal of Consumer Research, 21(3), 504-521.

Sarkar A., (2014). "Brand love in emerging market: a qualitative investigation", Qualitative Market Research: An International Journal, 17, $481-494$.

Shimp, T. A. \& Madden, T. J. (1988). "Consumer-object relations: A conceptual framework based analogously on Sternberg's triangular theory of love", ACR North American Advances.

Sirgy, M. J. \& Samli, A. C. (1985). “A path analytic model of store loyalty involving self-concept, store image, geographic loyalty, and socioeconomic status", Journal of the Academy of Marketing Science, 13(3), 265 291.

Sirgy, M. J. (1986). “A Quality-of-Life Theory Derived from Maslow's Developmental Perspective”. American Journal of Economics and Sociology, 45(3), 329-342.

Thomson, M., Macinnis, D. J. \& Park, C. W. (2005). “The ties that bind: Measuring the strength of consumers' emotional attachments to brands", Journal of consumer psychology, 15(1), 77-91.

Turgut, M.Ü. (2014). Marka sevgisinin marka güveni, olumsuz bilgiye karşı direnç ve tekrar satın alma niyeti çerçevesinde incelenmesi. Yüksek Lisans Tezi, Ankara, Hacettepe Üniversitesi Sosyal Bilimler Enstitüsü.

Veloutsou, C. \& Moutinho, L. (2009). "Brand relationships through brand reputation and brand tribalism”, Journal of Business Research, 62(3), 314-322.

Vernuccio, M., Pagani, M., Barbarossa, C \& Pastore, A. (2015). Antecedents of brand love in online network-based communities. A social identity pers pective. Journal of Product \& Brand Management, 24(7), 706-719.

Vlachos, P. A., Theotokis, A., Pramatari, K. \& Vrechopoulos, A. (2010). “Consumer-retailer emotional attachment: Some antecedents and the moderating role of attachment anxiety”. European Journal of Marketing, 44(9/10), 1478-1499.

Whang, Y.O., Allen, J., Sahoury, N. and Zhang, H. (2004), "Falling in love with a product: The structure of a romantic consumer-product relationship," Advances in Consumer Research, 31, 320-327.

Witt, R. E. \& Bruce, G. D. (1972). “Group influence and brand choice congruence”, Journal of Marketing Research, 9(4), 440-443. 